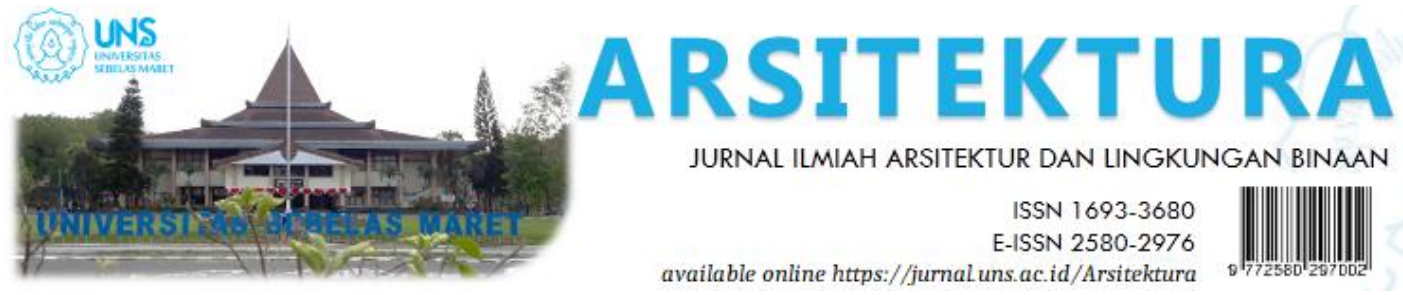

Volume 19 Issue 1 April 2021, pages:107-116

\title{
Strategi Pengembangan Arboretum Berbasis Arsitektur Ekologis di Hutan Pinus Pracimantoro Wonogiri
}

\section{Ecological Architecture Based Arboretum Development Strategy in Pracimantoro Pine Forest Wonogiri}

\author{
Bima Surya Limenta ${ }^{1 *}$, Wiwik Setyaningsih ${ }^{2}$, Purwanto Setyo Nugroho ${ }^{3}$, Ofita Purwani ${ }^{4}$ \\ Architecture Department, Faculty of Engineering, Sebelas Maret University ${ }^{1^{*}}$ \\ bimasurya133@student.uns.ac.id \\ Architecture Department, Faculty of Engineering, Sebelas Maret University ${ }^{2}$ \\ Architecture Department, Faculty of Engineering, Sebelas Maret University ${ }^{3}$ \\ Architecture Department, Faculty of Engineering, Sebelas Maret University ${ }^{4}$
}

DOI: https://doi.org/10.20961/arst.v19i1.45448

Received: November 6,2020 Revised: February 28,2021 Accepted: March 4,2021 Available online: April 30,2021

\begin{abstract}
Pracimantoro sub-district has quite high tourism potential but hasnot been utilized properly to improve the regional economy of Wonogiri Regency. The development of pineforests into arboretum designs is the rightchoice in realizing edu-tourism thatpays attention tonatural conservation throughecological concepts. This concept applies a forest area design with attention to environmental sustain ability and forest conservation. The arrangement of pine forest tourism areas is oriented to an emphasis on preserving nature, preserving local culture, and empowering the surrounding community. The research method used is qualitative and quantitative analysis based on data from various sources. The results of this study are recommendations for the benefits of arboretum development for the Pracimantoro sub-district.
\end{abstract}

Keywords: Arboretum, Edu-tourism of pine forest, environmental sustainability, ecological concept, Pracimantoro

\section{PENDAHULUAN}

Pracimantoro merupakan kecamatan yang berada di Kabupaten Wonogiri, berbatasan dengan wilayah Yogyakarta pada sebelah barat. Wilayah Pracimantoro memiliki luasan sebesar 142,14 $\mathrm{km}^{2}$, dengan area hutan seluas 346,63 ha yang terdiri dari hutan lindung dan produksi. Hutan produksi merupakan potensi bagi pengembangan sumber daya alam yang lebih optimal apabila dapat dimanfaatkan dengan baik dan memperhatikan prinsip kelestarian lingkungan. Hutan produksi menurut PP No. 24 tahun 2010 tentang kawasan hutan mengartikan hutan produksi merupakan kawasan hutan yang memiliki kegunaan utama menghasilkan hasil sumber 
daya hutan seperti pohon karet maupun pohon jati.

Selain berguna untuk menghasilkan kayu dan karet, hutan produksi juga dapat dimanfaatkan sebagai destinasi eduwisata yang dapat menunjang pengembangan ekonomi maupun sosial masyarakat. Pada tahun 2015-2018 tercatat peningkatan jumlah wisatwan lokal yang berkunjung ke tempat destinasi wisata di daerah kabupaten Wonogiri. Jumlah kunjungan wisatawan domestik paling banyak terjadi pada tahun 2017 sebanyak 483.146 wisatawan. Sementara paling kecil terlihat pada tahun 2015 sebanyak 358.239 wisatawan. Jumlah peningkatan ini berdasarkan data BPS dan BAPPEDA Wonogiri tahun 2018 yang terlihat mengalami fluktuasi pada tiap tahunnya dari jumlah kunjungan wisatawan.

Secara umum hutan memiliki fungsi sebagai penyerap karbondioksida $\left(\mathrm{CO}_{2}\right)$ sisa hasil pembakaran yang dapat merusak lapisan ozon, pohon-pohon pinus dapat berguna menyerap air hujan yang akan membentuk cadangan air tanah dan mencegah bencana longsor pada daerah perbukitan. Dalam hal pengelolahan hutan di Indonesia diatur dalam Undang-Undang RI No. 41 tahun 1999 tentang kehutanan dalam pasal 2 dituliskan bahwa "Kegiatan aktivitas didalam hutan harus berdasarkan manfaat dan kelestarian, keadilan, keterbukaan, kerakyatan, kebersamaan, dan keterpaduan."

Pemerintah daerah setempat berupaya dalam memberdayakan masyarakat lokal dan mengenalkan potensi kawasan daerah setempat tanpa merusak lingkungan alam yang ada. Menurut Soleman Imbiri (2015) pemanfaatan hutan sebagai tempat wisata alam dapat berupa resort, wisata sport tourism, dan kebun raya atau arboretum sebaiknya memperhatikan keberlanjutan dan kelestarian dari tatanan ekosistem hutan. Sehingga hutan yang mengalami pengembangan sebagai kawasan wisata tidak mengalami kerusakan yang akan menimbulkan kerugian bagi masyarakat setempat.

Pada penelitian ini akan menganalisa objek dari hutan pinus dalam menentukan rencana pengembangan wisata yang sesuai dalam memperhatikan kelestarian lingkungan dan memperdayaan masyarakat setempat. Melalui kajian dari potensi pemanfaatan pengembangan wisata ini diharapkan dapat menjadi acuan dalam menerapkan pembangunan kawasan hutan produksi khususnya hutan pinus menjadi kawasan wisata yang dapat meningkatkan perekonomian daerah dan memberdayakan masyarakat setempat.

\section{METODE}

Kajian pada penulisan ini dilakukan melalui data kondisi hutan produksi yang berupa hutan pinus dan tercatat dalam data pemerintah daerah setempat. Penulis menggunakan strategi pengambilan data melalui kualitatif dan kuantitatif. Sementara data-data secara kuantitatif didapatkan melalui data statistik dari pemerintah daerah yang dikomparasikan dengan rumus laju pertumbuhan eksponensial dalam memprediksi peningkatan kunjungan wisatawan pada 10 tahun mendatang. Kemudian data-data yang terkumpul akan dilakukan analisis indentifikasi dari tahap SWOT secara menyeluruh untuk mendapatkan potensi serta manfaat dari pengembangan wisata yang sesuai pada kawasan hutan pinus di Kecamatan Pracimantoro.

Tahapan SWOT menurut Eka Susanti (2018) dapat berisikan empat aspek meliputi kelemahan (weaknesses), Kekuatan (strengths), ancaman (Threats) dan terkahir peluang (opportunities. Hasil kajian dari SWOT pada salah satu area hutan pinus di Desa Wonodadi, Kecamatan Pracimantoro dapat dijadikan acuan dalam perencanaan pengembangan wisata daerah khususnya dalam wisata alam yang memperhatikan kelestarian untuk kawasan hutan.

Kajian meliputi manfaat yang akan didapatkan dari kawasan sekitar dan pemberdayaan masyarakat setempat dari pengembangan wisata yang menunjang kelestarian lingkungan alami hutan pinus untuk saat ini dan masa yang akan datang. Pemahaman tersebut melalui rangkaian diagram alur pola penyelesaian perencanaan pengembangan wisata yang sesuai dengan kawasan hutan pinus di Kabupaten Wonodadi. 


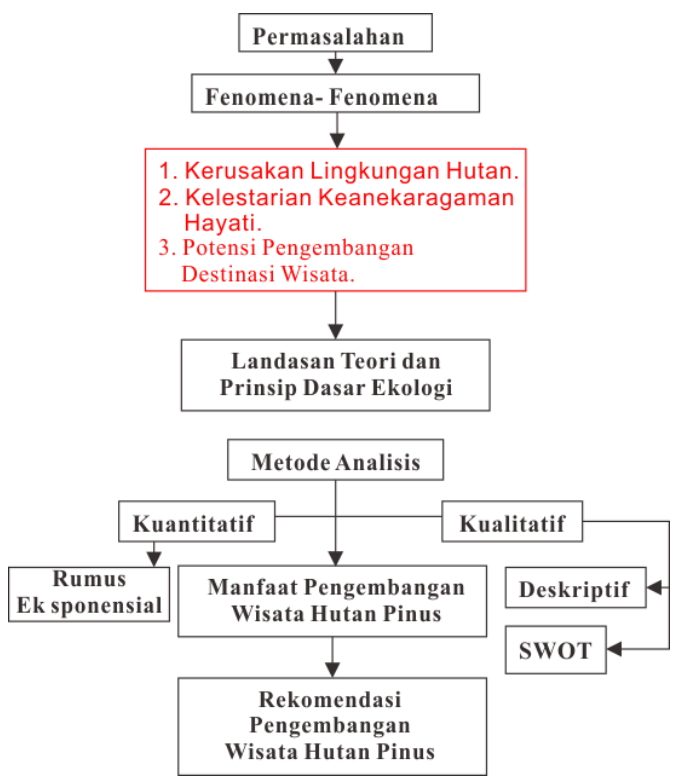

Gambar 1.Diagram alur pola pikir metode a nalisis

\section{HASIL DAN PEMBAHASAN}

Kawasan hutan produksi yang berada di Kecamatan Pracimantoro, Kabupaten Wonogiri secara keseluruhan seluas 399 ha. Kawasan hutan ditumbuhi oleh jenis pohon pinus, karet dan pepohonan lainnya. Selain itu ada tanaman produksi yang ditanam pada sekitar kawasan hutan seperti jagung, kacang tanah, ubi kayu dan kedelai dalam data BPS tahun 2018. Pada dasarnya mata pencaharian utama masyarakat setempat di kawasan ini berupa pertanian dan perkebunan yang masih perlu ditingkatkan potensi pemberdayaannya.

Jumlah penduduk Kabupaten Wonogiri tercatat sebesar 957.106 jiwa yang dikategorikan menjadi 491.982 jiwa penduduk berjenis kelamin perempuan dan 465.124 jiwa penduduk berjenis kelamin laki-laki. Berdasarkan data BPS tahun 2018 nilai pertumbuhan penduduk Wonogiri sejumlah 0,25 persen dengan kepadatan mencapai sebesar 525 jiwa $/ \mathrm{km}^{2}$. Pada kecamatan Pracimantoro yang berada di wilayah Wonogiri terletak diujung sebelah selatan dan memiliki ketinggian sekitar 253-600 mdpl. Daerah ini didominasi ole bukit lipatan batuan kapur dengan struktur tanah litosal mediteran coklat masam.

Kawasan hutan pinus yang dijadikan penelitian berada pada kawasan desa Wonodadi, Kecamatan Pracimantoro, Kabupaten

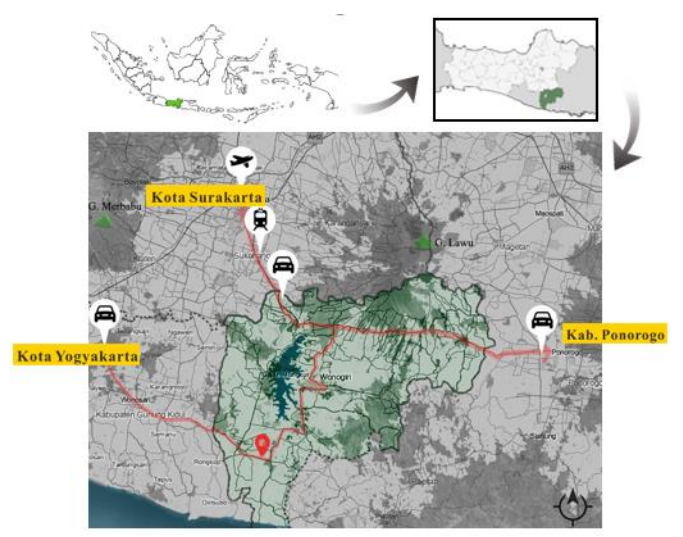

Gambar 2. Letak hutan pinus di wilay ah Kab. Wonogiri

Wonogiri. Area hutan produksi ini secara keseluruhan memiliki luasan sebesar 192 hektar yang berada di ketinggian 500-600 mdpl.

Pada wilayah hutan ini yang akan diobservasi hanya seluas 10,2 hektar yang berada di jalan desa salam wonodadi. Wilayah ini dipilih karena sudah menjadi daerah wisata hutan pinus yang dibangun sederhana oleh pemerintah daerah setempat.



Gambar 3. Letak area hutan pinus didesa

Wonodadi

Penelitian pada area hutan ini diharapkan dapat mengembangkan kawasan wisata hutan pinus menjadi lebih optimal. Menurut literatur dari museum karst di Pracimantoro berkaitan dengan fenomena eksokarst dan endokarst pada area kabupaten Wonogiri memunculkan suatu spesies flora maupun fauna yang beradaptasi di wilayah kering serta gelap. Jenis burung yang menempati kawasan hutan ini berupa jenis burung seperti kutilang, burung elang jawa, jalak, kelelawar dan sebagainya.

Potensi keanekaragaman flora dan fauna pada kawasan menjadi pertimbangan dalam pengembangan wisata untuk kelestarian 
lingkungan ekosistem pada kawasan hutan pinus tersebut.

Berikutnya setelah melihat potensi alam sekitar, secara kuantitatif dilakukan perhitungan prediksi pertumbuhan pengunjung wisatawan melalui rumus laju pertumbuhan eksponensial dari data jumlah wisatawan yang berkunjung ke Kabupaten Wonogiri dari tahun 2014 dan 2018.

Tahun 2014 pengunjung yang datang sebanyak 358.330 wisatawan lokal dan tahun 2018 sebanyak 430.967 wisatawan lokal. Rumus proyeksi dari pertambahan laju pertumbuhan eksponensial adalah sebagai berikut.

$\mathrm{Pt}=\mathrm{Pox} \mathrm{e}^{\mathrm{r} . \mathrm{t}} \mathrm{dan} \mathrm{r}=\frac{1}{t} \operatorname{In} \frac{p o}{p t}$

Keterangan :

$\mathrm{Pt}=$ Besaran jumlah wisatawan dalam tahun $\mathrm{t}$ (2014)

$\mathrm{t}=$ Jangka waktu

Po $=$ Besaran jumlah wisatawan pada tahun dasar

(2018)

$\mathrm{r}=$ Laju dari pertumbuhan wisatawan,

$\mathrm{e}=$ bilangan eksponensial $(2,7183)$

Keseluruhan perhitungan menjadi berikut ini.

$$
\mathrm{r}=\frac{1}{4} \operatorname{In} \frac{430.967}{358.330} \longrightarrow \mathrm{r}=0,0455=0,455 \%
$$

Perkiraan dari besaran pengunjung dalam sepuluh tahun ke depan pada tahun 2030 setelah didapatkan laju pertumbuhan wisatawan akan sebagai berikut.

$$
\begin{aligned}
& \mathrm{Pt}=\text { Pox e } \mathrm{e}^{\text {r.t }} \longrightarrow \mathrm{P}_{2030}=358.330 \times 2,7183^{0,0455 \times 10} \\
& \mathrm{P}_{2030}=564.792 \text { orang }
\end{aligned}
$$

Laju pertumbuhan wisatawan Kab. Wonogiri Berdasarkan hitungan diatas akan sebanyak 564.792 wisatawan lokal. Jumlah ini belum termasuk dalam wisatawan mancanegara ketika tahun 2030. Potensi yang cukup besar ini harus dapat dimanfaatkan secara optimal untuk meningkatkan perekonomian masyarakat dan memberdayakan masyarakat setempat dalam pengembangan di daerah Kecamatan Pracimantoro, Kabupaten Wonogiri. Pengembangan wisata alami pada hutan harus memperhatikan area zonasi bagi area konservasi hutan, area alami jalur fauna, dan area jalur manusia maupun kendaraan yang melintas pada kawasan huatn pinus.

Strategi pengembangan wisata pada area hutan dapat membagi zona-zona khusus yang menciptakan tatanan ekosistem pada area lanskap tidak terganggu oleh aktivitas dari wisatawan yang datang. Area konservasi hutan harus menjadi area dengan tingkat lingkup yang terlindungi dari kebisingan pergerakan kendaraan atau manusia yang berlebihan dapat menyebabkan fauna di hutan terganggu. Pada akhirnya fauna tersebut dapat meninggalkan kawasan hutan atau mati akibat stress dari pola aktivitas yang berubah pada tatanan lingkup hutan.

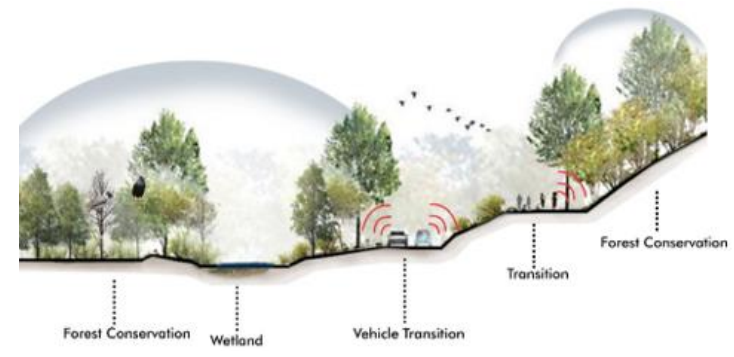

Gambar 4. Pengembangan zona khusus di hutan Sumber:https://www.coachelacaille.com/ev

Sementara analisis mengenai dampak pada area kawasan hutan pinus di desa Wonodadi, Kabupaten Wonogiri akan dilakukan analisis untuk menemukan faktor-faktor positif dan negatif yang membantu mengembangkan kawasan hutan menjadi area wisata yang sesuai dengan tatanan ekosistem alaminya. Peluangpeluang pendukung serta permasalahan yang akan didapatkan dari pengembangan ini diharapkan setelah dianalisis dapat menghasilkan solusi atau strategi penyelesaian masalah yang kemungkinan timbul pada area hutan. Pada analisis menggunakan tabel SWOT yang disusun dalam mengidentifikasi kelemahan (weaknesses), Kekuatan (strengths), ancaman (Threats) dan terkahir peluang (opportunities). dari kondisi hutan yang akan dikembangkan menjadi kawasan wisata alam dengan penekanan secara ekologis. 
Tabel 1. Pengamatan hasil kajian SWOT di wilayah Kecamatan Pra cimantoro.

\begin{tabular}{|c|l|}
\hline \multicolumn{1}{|c|}{ Strength } \\
\hline 1. & $\begin{array}{l}\text { Pracimantoro semakin dikenal sebagai } \\
\text { kawasan wisata yang memperhatikan } \\
\text { kelestarian pada lingkungan hutan. }\end{array}$ \\
\hline 2. & $\begin{array}{l}\text { Peningkatan perekonomian daerah } \\
\text { setempat karena area semakin dikenal dan } \\
\text { dikunjungi oleh wisatawan lokal serta } \\
\text { mancanegara. }\end{array}$ \\
\hline 3. & $\begin{array}{l}\text { Pemberdayaan masyarakat lokal untuk ikut } \\
\text { berpartisipasi dalam meningkatkan hasil } \\
\text { pengolahan hutan produksi. }\end{array}$ \\
\hline 4. & $\begin{array}{l}\text { Peningkatan pengenalan akan budaya lokal } \\
\text { yang menjadi ciri khas dari Kabupaten } \\
\text { Wonogir melalui industri wisata lokal. }\end{array}$ \\
\hline 2.
\end{tabular}

Tabel 1 menunjukkan faktor-faktor yang berkaitan dengan nilai negatif berupa kelemahan (weaknesses) dan ancaman (threats) di kawasan hutan Pinus, Kecamatan Pracimantoro. Faktor negatif ini menjadi perhatian dalam perencanaan pengembangan wisata sehingga masyarakat dan alam sekitar dapat merasakan dampak positif yang optimal. Sementara pada faktor positif menjadi penguatan dan membantu dalam ranah pengembangan potensi alam serta masyarakat setempat untuk menciptakan pengembangan wisata hutan pinus menjadi wisata ekologis yang menjaga kelestarian lingkungan alami hutan.

Dari paparan di atas untuk mengembangkan wisata hutan pinus yang berbasis lingkungan alami akan dikaitkan dengan beberapa pertimbangan wisata alam meliputi pengembangan resort, sport tourism, dan arboretum atau kebun raya. Pemilihan wisata alami hutan pinus yang sesuai akan ditemukan melalui analisis SWOT berdasarkan pada wisata alam seperti resort, sport tourism, dan arboretum atau kebun raya. Pengertian dari masing-masing wisata alam sebagai berikut. Pertama, resort merupakan suatu kawasan yang direncanakan bukan hanya untuk sekedar menginap akan tetapi juga berguna untuk rekreasi dan istirahat untuk menikmati keindahan alam di daerah tersebut (Chuck Y. Gee, 1988). Kemudian pengertian sport tourism Menurut Undang-Undang Republik Indonesia Nomor 3 Tahun 2005 tentang Sistem Keolahragaan Nasional, Pasal 1 ayat 12 mengatakan bahwa olahraga rekreasi merupakan olahraga yang dilaksanakan oleh warga dengan kemampuan dan kemauan untuk berkembang serta tumbuh sesuai dengan nilai dari budaya lokal yang berguna bagi kesehatan maupun kebugaran tubuh. Oleh karena itu, olahraga dan pariwisata memiliki tujuan yang sama.

Sementara pengertian arboretum merupakan kawasan yang terdiri dari berbagai jenis tanaman pepohonan yang tumbuh secara in-situ dan ex-situ serta dapat digunakan untuk keperluan penelitian dan pelestarian tanaman (Moestrup \& Harum, 2016). Arboretum adalah taman kebun yang memiliki koleksi jenis-jenis pohon yang ditanam dengan luasan tertentu serta dapat mengikuti habitat aslinya atau area dari pelestarian keanekaragaman hayati. Area hutan ini minimal dapat memperbaiki atau menjaga kondisi iklim didalam lingkungannya. Selain itu, arboretum diharapkan dapat berperan menjadi sarana penelitian, dan pengembangan, serta dapat berupa Pendidikan 
(Napolion, 2015). Setelah memahami pengertian masing-masing wisata alam yang menjadi alternatif pengembangan wisata pada kawasan hutan pinus diterapkan kajian analisis melalui tabel 2 berikut ini.

Tabel 1. Indentifikasi SWOT berkaitan dengan opsi dari wisa ta alam pada hutan pinus.

\begin{tabular}{|c|c|c|}
\hline Resort & $\begin{array}{c}\text { Sport } \\
\text { Tourism }\end{array}$ & Arboretum \\
\hline $\begin{array}{l}\text { Tidak menjamin } \\
\text { kelestarian } \\
\text { hutan berfokus } \\
\text { kepada tempat } \\
\text { penginapan }\end{array}$ & $\begin{array}{l}\text { Tidak } \\
\text { menjamin } \\
\text { kelestarian } \\
\text { hutan } \\
\text { berfokus } \\
\text { kepada } \\
\text { olahraga alam } \\
\text { bebas }\end{array}$ & $\begin{array}{l}\text { Dapat menjamin } \\
\text { kelestarian } \\
\text { hutan yang } \\
\text { berfokus kepada } \\
\text { penelitian dan } \\
\text { konservasi } \\
\text { huatn }\end{array}$ \\
\hline \multicolumn{2}{|c|}{$\begin{array}{l}\text { Tidak perlu melibatkan } \\
\text { pemberdayaan masyarakat } \\
\text { setempat }\end{array}$} & $\begin{array}{l}\text { Perlu } \\
\text { melibatkan } \\
\text { pemberdayaan } \\
\text { masyarakat } \\
\text { setempat }\end{array}$ \\
\hline \multicolumn{2}{|c|}{$\begin{array}{l}\text { Tidak perlu mengetahui } \\
\text { karakteristik alam sekitar }\end{array}$} & $\begin{array}{l}\text { Perlu } \\
\text { mengetahui } \\
\text { karakteristik } \\
\text { alam sekitar }\end{array}$ \\
\hline \multicolumn{2}{|c|}{$\begin{array}{l}\text { Tidak perlu memanfaatkan } \\
\text { potensi budaya lokal }\end{array}$} & $\begin{array}{l}\text { Dapat } \\
\text { memanfaatkan } \\
\text { budaya lokal } \\
\text { dalam } \\
\text { penambahan } \\
\text { atraksi wisata } \\
\text { edukasi }\end{array}$ \\
\hline \multicolumn{2}{|c|}{$\begin{array}{l}\text { Tidak perlu memanfaatkan hasil } \\
\text { hutan ataupun melakukan } \\
\text { pelestarian hutan. }\end{array}$} & $\begin{array}{l}\text { Dapat } \\
\text { memanfaatkan } \\
\text { hutan produksi } \\
\text { secara lestari }\end{array}$ \\
\hline $\begin{array}{l}\text { Dapat } \\
\text { menimbulkan } \\
\text { kerusakan } \\
\text { lingkungan } \\
\end{array}$ & $\begin{array}{l}\text { Tidak } \\
\text { menganggu } \\
\text { kerusakan } \\
\text { lingkungan }\end{array}$ & $\begin{array}{l}\text { Dapat } \\
\text { mengembangka } \\
\mathrm{n} \text { kelestarian } \\
\text { lingkungan } \\
\end{array}$ \\
\hline \multicolumn{3}{|c|}{$\begin{array}{l}\text { Dapat diambil alih pemanfaatannya oleh kapitalis } \\
\text { untuk keuntungan pribadi }\end{array}$} \\
\hline
\end{tabular}

Hasil dari analisis SWOT yang berkaitan dengan pemanfaatan wisata alam baik yang dapat menguatkan dampak positif maupun negatif dari pembangunan wisata alam berbasis lingkungan di hutan pinus desa Wonodadi yang lebih condong ke arah wisata alam berupa arboretum atau kebun raya. Wisata alam yang berupa arboretum dapat mengoptimalkan beberapa dampak positif dari kegiatan pengembangan wisata alam dan memberikan solusi dari cara mengantisipasi dampak negatif yang timbul akibat pembangunan wisata alam ini. Hasil penerapan objek ini akan dikaitkan dengan basis pembangunan yang menekankan pada aspek ekologis sebagai penghubung pembangunan dengan tatanan lingkungan ekosistem hutan.

Pendekatan arsitektur ekologis pada perencanaan dan perancangan kawasan wisata harus dilakukan untuk memastikan dilakukan penataan yang baik dan memperhatikan potensi-potensi yang ada di sekitar kawasan tersebut agar dapat dikembangkan secara lebih optimal dengan tetap melakukan perencanaan pembangunan berkonsep eco-culture. Pendekatan arsitektur ekologis juga merupakan salah satu upaya dalam perencanaan dan perancangan kawasan desa wisata yang berkelanjutan, baik dari sisi alam, budaya maupun masyarakatnya (Ayudya, 2018).

Penerapan pendekatan arsitektur ekologis menjadi katalis yang menghubungkan pembangunan dengan alam sekitar dalam menerapkan pembangunan yang berkelanjutan dan ramah lingkungan. Menurut Prasetyo (2018), teori-teori desain ekologis dalam penerapannya di Indonesia harus dipahami bahwa arsitektur nusantara merupakan arsitektur yang hidup menyatu dengan lingkungan alam dan lingkungan sosialnya, bukan arsitektur yang bersifat individual. Menurut Heinz Frick (1998) dalam arsitektur ekologis berasal dari kata eco yang memiliki arti sebagai hubungan timbal balik antara makhluk hidup dengan lingkungan alaminya berkaitan dengan empat aspek berikut ini.

Pertama, Holistik yang dapat dipahami sebagai hubungan dengan seluruh sistem keseluruhan atau menjadi satu kesatuan yang lebih dari sekedar kumpulan dari hanya kumpulan bagian-bagian tertentu. Kedua, memanfaatkan pengalaman hubungan manusia meliputi tradisi dan pengalaman lingkungan alam sekitar pada pembangunan. Ketiga, melihat pembangunan sebagai suatu proses dan tidak menjadi kenyataan tertentu yang statis. Terakhir, perlunya adanya kerja sama yang dilakukan antara manusia dengan alam sekitar dalam pembangunan suatu kawasan untuk menciptakan keharmonisan alam dan mencegah 
kerusakan lingkungan. Penulisan ini beryujuan untuk melihat potensi manfaat dari pembangunan arboretum pada kawasan hutan pinus di Kecamatan Pracimantoro, Kabupaten Wonogiri.

Menurut Ken Yeang (1999) merupakan salah satu tokoh dalam arsitektur asia terkenal dengan konsep ekologis untuk mengembangkan dasar pertimbangan pemikiran dari arsitektur ekologi yang meliputi :

a. Tatanan dari lingkungan dalam bangunan luar menuju dalam yang membentuk lansekap secara alami.

b. Penataan dari konfigurasi pada bangunan

c. Pendayagunaan potensi iklim untuk keperluan bangunan

d. Penerapan dari teknologi yang tepat guna serta efisien.

e. Mempertimbangkan aspek dari sosial budaya yang mempengaruhi penghuni terhadap bangunan.

Sementara menurut tokoh Cowan dan Ryn (1996) mengatakan bahwa prinsip-prinsip dalam desain ekologis adalah berikut ini :

a. Solution Grows from Place, mencari solusi pada keseluruhan dari masalah desain berasal yang terdapat di lingkungan untuk menjadi objek arsitektur terbangun. Prinsipnya bermanfaat untuk pengembangan potensi dan sumber daya yang tersedia serta mengatasi permasalahan pada desain yang dikaitkan dengan aspek sosial budaya.

b. Ecological Acounting Informs Design, beguna dalam memperkecil atau mengurangi dampak buruk bagi lingkungan melalui perhitungan data-data ekologis. Sehingga hasil dari rancangan desain yang akan dipilih dapat mengurangi kemungkinan memberikan dampak buruk terhadap lingkungan.

c. Design with Nature, produk arsitektur diharapkan mampu melestraikan setiap unsur-unsur dari ekosistem sehingga tidak merusak lingkungan habitat alam. Prinsip yang diperhitungkan melalui proses dalam lingkungan yang mau diubah atau dikembangkan.

d. Everyone is a Designer, Proses dalam mendesain perlu memperhatikan setiap pihak dalam berkerjasama untuk memperbaiki lingkungan. Karena setiap yang berperan akan menjadi patner desain

e. Make Nature Visible, titik utama dalam arsitektur terbentuk proses siklis, yaitu proses yang dilalui secara alami dan membantu mengurangi limbah yang dikeluarkan.

Penggunaan energi alternatif dapat memperbesar dari restorasi ekologi yang dapat mengoptimalkan potensi didalam alam. Kemudian, perubahan energi terkait sistem utilitas bangunan yang menerapkan ekologi berguna memperkecil, daur ulang, dan memakai kembali energi. Prinsip-prinsip ekologi tersebut akan membentuk bangunan yang ramah lingkungan dan meningkatkan pengembangan upaya konservasi lingkungan secara berkelanjutan (Lois, 2018). Dengan demikian, prinsip-prinsip arsitektur ekologis dapat disimpulkan di atas dapat diambil garis besarnya sebagai berikut: bangunan yang mampu memperhitungkan pemanfaatan iklim terhadap bangunan, penggunaan pada bahan alami yang lebih ramah lingkungan, tercipta sistem energi matahari yang bertujuan menghemat energi, serta melindungi kelanjutan dari keanekaragaman biologis (NH, 2019).

Prinsip desain EcoMasterpalnning dari Ken Yeang didapatkan melalui suatu sistem yang hidup dinamis bersifat interaktif, fungsional dan biointegration yang akan membentuk:

1. Infrastruktur hijau (Ecoinfrastructure), adalah insfratruktur yang terdapat di alam secara alami menjadi infrastruktur dalam bangunan

2. Infrastruktur biru, merupakan infrastruktur yang berkaitan dengan sistem air meliputi drainase serta konservasi dari sistem air. Sistem ini melalui pengolahan hidrologi keseluruhan yang mengurangi pencemaran dari limbah cair yang telah dibuang.

3. Infrastruktur abu-abu, merupakan sistem infrastruktur buatan seperti saluran air/selokan, jalan raya, dan utilitas bangunan, serta dukungan sistem lainnya yang memberikan dampak berkelanjutan.

4. Infrastruktur Merah, merupakan infrastruktur terhubung hubungan manusia didalam lingkungan binaa atau enclosure dan hardscapes serta berkaitan dengan 
sistem social, perekonomian, legislatif dan aktivitas.

Pada implementasi terhadap pola dari perencanaan arsitektur yang bersifat ekologis memperhatikan permasalahan-permasahan seperti contohnya dalam tingkatan sistem penggunaan energi, iklim, kualitas struktur terhadap bangunan, maupun area penghijauan di lingkungan (Jannifer, 2017). Dalam penerapan energi mempunyai suatu tingkatan dari sistem operasi beikut ini.

1) Mode pasif meliputi penggunaan konsumsi energi dengan tingkatan paling rendah atau mengurangi penggunaan dari peralatan mekanikal eletrikal berkaitan dalam sumber daya alam yang tidak dapat diperbaharui.

2) Mode penggabungan adalah penyerapan konsumsi energi sebagian bergantung dari energy dependent maupun energi yang berasal dari mekanikal eletrikal.

3) Mode aktif merupakan semua dari penggunaan energi yang berasal dari alatalat mekanikal eletrikal berkaitan dalam sumber daya alam yang tidak dapat diperbaharui.

4) Mode produktif adalah semua penggunaan dari energi yang berasal dari sistem yang dapat membangkitkan energi sendiri atau seperti pada sistem panel surya

Berkaitan dengan pola perencanaan secara ekologis selalu menggunakan energi dari lingkungan alam sekitar antara lain:

1. Energy intensity yang dipakai atau yang terdapat dalam material bangunan harus sedikit mungkin dipergunakan.

2. Pada perhitungan kekuatan struktur harus memperhatikan aspek dari penerapan arsitektur ekologi di bangunan.

3. Perencanaan orientasi bangunan harus meperhatikan pertimbangan arah gerak matahari dari timur ke barat sehingga pada sisi bangunan yang mengarah ke utara dan selatan mendapatkan cahaya matahari yang lebih kecil.

4. Penutup atap dan dinding yang dirancang harus mampu beradaptasi dengan iklim setempat yang dapat melindungi dari panas matahari, hujan dan angin.
5. Perancangan bangunan harus menerapkan pertimbangan penggunaan energi-energi yang alami dan memperkecil penggunaan dari energi yang tidak dapat diperbaharui.

6. Mempertimbangkan kenyamanan thermal pada bangunan untuk mendapatkan thermal yang optimal perlu melihat penataan dari area penghijauan dan bukaan pada bangunan.

Penerapan aspek ekologis terhadap desain arboretum perlu mempertimbangkan aspek terhadap unsur-unsur sebagai berikut :

a. Aspek perlindungan hutan.

b. Mengurangi pemakaian energi yang tidak dapat diperbarui.

c. Mengoptimalkan penggunaan dari energi yang dapat diperbaharui seperti energi angin, air, dan matahari.

d. Mempertimbangkan aspek budaya, ekonomi maupun sosial masyarakat.

e. Penggunaan dari teknologi yang tepat guna.

f. Mempertimbangkan iklim pada area setempat khusunya iklim tropis.

g. Menerapkan aplikasi bahan bangunan yang ramah terhadap lingkungan.

h. Pengaplikasian terhadap penataan vegetasi atau tanaman di dalam bangunan.

i. Menerapkan aplikasi aspek daur ulang, pemakaian kembali, dan mengurangi limbah.

\section{KESIMPULAN}

Penulis menyimpulkan terdapat beberapa hal pokok berkaitan pemanfaatan pengembangan arboretum sebagai wisata yang berbasis kelestarian lingkungan.

Pertama, kawasan Kabupaten Wonogiri memiliki potensi kunjungan wisatawan yang cukup besar berdasarkan rumus perhitungan laju pertumbuhan eksponensial. Potensi ini harus dapat dimanfaatkan oleh pihak pemerintah dan masyarakat lokal serta dapat memanfaatkan bentang alam yang indah dalam kawasan kars yang berada di Kabupaten Wonogiri. Potensi ini sangat menunjang dalam pengembangan perencanaan wisata alam yang tidak merusak lingkungan dan dapat mengenalkan budaya lokal.

Kedua, Potensi keanekaragaman flora dan fauna karena karakteristik batuan kars yang 
tercipta pada area Kabupaten Wonogiri. Potensi ini harus dilihat dalam pengembangan area yang tidak merusak tatanan ekosistem alami yang ada serta dalam setiap pengembangan destinasi wisata seperti arboretum diharapkan dapat menjaga kelestarian lingkungan melalui konservasi hutan. Hutan yang dimaksud dapat berupa hutan produksi maupun hutan lindung yang ditanami pohon pinus serta pepohonan lainnya.

Ketiga, pengembangan area wisata seperti zonasi pada area arboretum membantu dalam pengembangan destinasi wisata yang memberikan akses jalur khusus sehingga fauna yang berada di area hutan pinus tidak terganggu oleh aktivitas dari wisatawan yang berkunjung.

Keempat, pemerintah daerah dapat memberikan arahan serta pendampingan kepada masyarakat setempat untuk memiliki kesadaran pentingnya menjaga kelestarian alam dan budaya lokal setempat. Hal ini menjadi penting dalam pengelolaan pengembangan seperti wisata alam berupa arboretum dapat memberikan dampak positif untuk pembangunan daerah serta tatanan lingkungan alam sekitar tetap lestari.

Kelima, arsitektur ekologi perlu mempertimbangkan aspek lingkungan berkaitan dengan keberlanjutan, penghematan energi, aspek iklim dan pelestarian keanekaragaman hayati. Pertimbangan ini bertujuan untuk memberi kesimbangan pada ekosistem alam dengan aktivitas manusia di dalamnya. Pertimbangan terhadap aspek ini untuk menerapkan kelestarian hutan di daerah Kabupaten Wonogiri.

\section{UCAPAN TERIMAKASIH}

Penulis berterima kasih kepada pihak-pihak terkait yang terlibat dalam membantu keberhasilan dari penelitian ini, baik berasal dari pihak-pihak pemerintah daerah di Kecamatan Pracimantoro serta masyarakat setempat yang telah turut serta memberikan dukungan sehingga penelitian ini dapat terselesaikan dengan baik. Tulisan ini didanai melalui Hibah Grup Riset PNBP UNS tahun pendanaan 2020.

\section{REFERENSI}

Ayudya, D. 2018. Eksplorasi Arsitektur Ekologis di Desa Wisata Kampung Sindangbarang. Jurnal Vitruvian. 7(3): 80.

Chrisnesa, Jannifer Shellyn (2017) Gedung Resepsi Pernikahan Paripurna Dengan Pendekatan Arsitektur Ekologis di Yogyakarta. S1 thesis, UAJY. Available from : http://e-journal.uajy.ac.id/11941/

Lois, Suparno, Kusumaningdyah, NH. 2018. Penerapan Ekologi dalam Perancangan Pusat Konservasi Rawa Pening di Kabupaten Semarang. Jurnal Senthong. 1(2): 214.

Marzaman, A., \& Rasyid, A. U. (2020). Eduwisata Bahari Berbasis Pemberdayaan Masyarakat dalam Pengembangan Taman Laut Olele, Kab. Bone Bolango, Provinsi Gorontalo. Jurnal Master Pariwisata (JUMPA), 06, hlm. 267-289. Available from :

https://doi.org/10.24843/jumpa.2020.v 06.i02.p02

Moestrup, S. \&, \& Harum, F. (2016). Technical Guideline for Arboretum Establishment in West Manggarai District, Flores, Indonesia. 1-8. Available from :

https://www.researchgate.net/publicati on/307876058_Technical_Guideline_f or_Arboretum_Establishment_in_Wes t_Manggarai_District_Flores_Indonesi a [diakses 01 November 2020]

Nasution, Rahma Dewi. 2017. Perencanaan Lanskap untuk Pengembangan Wisata Alam di Sempdan Sungai Kemiri Kecamatan Margadana-Kota Tegal. Jurnal Rekayasa, Teknologi, dan Sains. 1(2): 4.

Napolion, H., Sribudiani, E., Arlita, T. 2015. Pemahaman Pengunjung terhadap Arti dan Fungsi Arboretum Universitas Riau. Jurnal JOM Faperta. 2(2).

NH, Maria Kinanthi Sakti, Setyaningsih, W., Kusumaningdyah, NH. 2019. Penerapan Prinsip Arsitektur Ekologis pada Pengembangan Agrowisata Teh Kemuning di Karanganyar. Jurnal Senthong. 2(1): 164. 
Prasetyo, L., Tobing, R. R., dan Budiyuwono, H. 2018. Konsep Ekologis dan Budaya pada Perancangan Hunian Paska Bencana di Yogyakarta. Jurnal Teknik Arsitektur ARTEKS. 2(2): 128.

Winarto, Y., Setyaningsih, W., \& Yuliani, S. (2019). Sustainable Ecological Tourism Regional of Disaster Response In Pacitan, East Java. Arsitektura.

Available from : https://doi.org/10.20961/arst.v17i1.24 476

Imbiri, S. (2015). Pengelolaan Kawasan Hutan Taman Wisata Alam Gunung Meja di Kabupaten Manokwari. Jurnal Kehutanan Papuasia, 1(1), 36-52.

Susanti, E.(2018). Implementasi Analisis Swot Dalam Perencanaan Peningkatanmutu Pendidikan Di Madrasah Tsanawiyah Negeri 2 Kota Palembang (Doctoral dissertation, UIN RADEN FATAH PALEMBANG). 